\title{
Within and between species scaling in the weight, water, carbon and nitrogen contents of eggs and neonate larvae of twelve satyrine butterflies (Lepidoptera: Nymphalidae)
}

\author{
ENRIQUE GARCÍA-BARROS \\ Department of Biology (Zoology), Faculty of Sciences, Universidad Autónoma de Madrid, E-28049 Madrid, Spain; \\ e-mail: garcia.barros@uam.es
}

Key words. Allometry, carbon, chorion, egg, elemental-composition, larvae, Lepidoptera, nitrogen, Nymphalidae, reproduction, size

\begin{abstract}
The fresh weight, dry weight, and C and N content of the eggs, egg shells and neonate larvae of several satyrines were measured. This was done in order to assess the specificity of the composition of the egg and larvae, the phylogenetic or ecological nature of the variation and the existence of structural constraints on the composition of the offspring. All the traits investigated were found to be highly species-specific. The nature of the variation was not primarily phylogenetic, suggesting that the composition of the offspring has an ecological meaning. However, only a slight association was detected between three life history traits or habitat features and the compositions of the eggs or larvae, namely: female egg dropping was associated with a high $\mathrm{C}$ content of the eggs, xerophily with a high $\mathrm{C}: \mathrm{N}$ ratio, and a high content of $\mathrm{N}$ in the larvae with egg diapause. The evidence for intra-specific allometry between the traits investigated and egg weight varied among the species, suggesting that the slope of such relationship may be a specific feature. There was a close to isometric relationship between $\mathrm{C}$ and $\mathrm{N}$ contents in every species. Therefore simple $\mathrm{C}: \mathrm{N}$ ratios are independent of egg size, hence they can be used directly in comparative studies. Across species analyses indicated that small offspring contained a proportionally low amount of carbon and had a high dry matter content, suggesting that selection for small eggs was accompanied by selection for an enhanced proportion of nitrogen per egg. Finally, the species with large adult females invested comparatively more nitrogen per egg, which indicates a potential, constraint-based advantage of large adult size.
\end{abstract}

\section{INTRODUCTION}

Life history theory predicts that females should produce eggs of a size and number that maximizes maternal fitness (Smith \& Fretwell, 1974; Roff, 2002). However, size per se may be not the actual target for selection, since other egg properties are likely to co-vary with egg weight (Fischer et al., 2003). It is known that the elemental composition of some invertebrate eggs differs between species and populations and is correlated with habitat features (Baur \& Baur, 1998; Anger et al., 2002). Concerning Lepidoptera, an adaptive value has been attributed to both egg size (Nakasuji, 1987; Fischer \& Fiedler, 2001) and other features such as egg density or shell thickness (Thomas et al., 1991; Chauvin \& Vannier, 1997). However, with a few remarkable exceptions (e.g., references in Fehrenbach, 2003), the range of intra- and inter-specific variation in the composition of the eggs of these insects remains broadly unknown. The same holds for correlations between egg size and other egg properties. Common practice suggests that the eggs of different species might have different elemental compositions, and that this deserves careful consideration: a dominantly phylogenetic or adaptive explanation of the egg features would indicate the kind and level of selection that determines egg properties.

The analyses needed to compare the proportions of materials invested in an egg may be complex. Evolutionary change in body size is seldom free of adjustments to body proportions due to physiological or mechanical requirements (structural allometry), which may constrain variation in egg number and other properties (SchmidtNielsen, 1984; Reiss, 1989; Sinervo, 1993). As long as egg size is subject to physical laws comparable to those that govern adult body size, egg size variation should be associated with changes in the egg structure or composition. In spite of the efforts devoted to describe the relations between egg and adult size in insects (Berrigan, 1991; Honěk, 1993), no attention has yet been paid to scaling rules that may operate within the eggs themselves (Fox \& Czesak, 2000). This fact is illustrated by the widespread use of $\mathrm{C}: \mathrm{N}$ ratios to broadly denote the amount of energy reserves relative to protein content in insect and other invertebrate eggs (e.g. Forte et al., 2002; O'Brien et al., 2004). Simple proportions like the $\mathrm{C}: \mathrm{N}$ ratio may be expressed $C / N=a$, hence $C=a(N)$. This may take the form of the allometric equation (Gould, 1966; Reiss, 1989), $C=a(N)^{b}$, or $\log (C)=\log (a)+$ $b(\log N)$, under the assumption that $b=1.00$. This assumption has not been tested, and a value of $b$ different from 1.00 (allometric scaling) would imply that the $\mathrm{C}: \mathrm{N}$ ratio is different at different absolute concentrations of $\mathrm{C}$ or N. Furthermore, it has not been demonstrated that the total weights of $\mathrm{C}$ and $\mathrm{N}$ are constant across the range of variation of egg weight within a species. While this may be difficult to assess for e.g. body tissues, it can be readily tested in eggs (eggs are whole organisms, so estimates of dry body weight refer to the dry weight of a whole egg rather than a part of it). Moreover, other biologically relevant egg properties may be related to egg weight by non-isometric functions within and across spe- 
cies, including the proportion of the original egg reserves allocated to neonate larval soma or to egg shell, and the amount of water invested per egg (which may be crucial in dry habitats). If these elements can be measured together with the $\mathrm{C}$ and $\mathrm{N}$ contents, their patterns of covariation and dependence on total egg size can be tested by means of traditional allometric techniques (e.g., Reiss, 1989; Fairbairn, 1997).

The butterflies (Lepidoptera, Papilionoidea) are of special interest for studies on size-dependent egg composition, because the amount of one element required to build the eggs (nitrogen) is largely fixed before adult eclosion. Nitrogen compounds are essential for vitellogenesis (Rivero \& Casas, 1999; Shapiro \& Ferkovich, 2002; Wall et al., 2002), while flower nectar (the main food source of adult butterflies) is usually poor in amino acids (e.g., Boggs, 1997). Thus, even if adult females can gather limited amounts of amino acids from nectar (Mevi-Schütz \& Erhardt, 2005), puddling (Arms et al., 1974; Beck et al., 1999; Boggs \& Dau, 2004 but cf. Molleman et al., 2005) or spermatophores (Stjernholm \& Karlsson, 2000; Wedell \& Karlsson, 2003), most of the nitrogen to be allocated to the eggs has to be obtained by the larval stages (Boggs \& Ross, 1993; O'Brien et al., 2004). On the other hand, the carbon-derived elements come from both, the larval and adult diets (Boggs, 1997; O'Brien et al., 2002, 2004). All else being equal, limited availability of one of the elements required to produce viable eggs may functionally constrain (e.g., Schwenk, 2002) either fecundity (if egg size and composition are kept constant), egg size (if egg composition and number have to be maintained), or egg size and composition (if the prevailing selection is for fecundity). Therefore under the assumptions that : 1maximizing fecundity is important, and 2- eggs need constant element ratios for physiological reasons (or for other reasons, including protection against environmental factors), egg size variation might be constrained by the availability of $\mathrm{N}$ at pupation. If so, the need for "fixed proportions" of the egg components should be revealed by a relatively invariant, size-independent design of the eggs within each species. Alternatively, in butterflies, variation in egg size across individuals and species is predicted to co-vary along with changes in the egg composition to buffer variation in the amount of nitrogen accumulated by the larvae. While the size of butterfly eggs varies broadly within and across species (e.g., Wiklund \& Persson, 1983; Nakasuji \& Kimura, 1984; García-Barros, 2000; Fischer \& Fiedler, 2001), few studies have focused on the elemental compositions of butterfly eggs (Fisher et al., 2004; O'Brien et al., 2004); nothing is known about the way in which the egg components are distributed between larval soma and the egg shell.

The aim of the present study is to assess the scaling relations of the egg components (dry matter, water, carbon and nitrogen contents) to total egg weight, as well as to determine how these relate to the neonate composition within and across-species, under near natural conditions for each species. The questions addressed are: (i) do the eggs and newly hatched larvae of different species have different elemental compositions and water contents? And if so, is the variation explained by phylogenetic relatedness, or by ecological adaptation? (ii) Does the egg composition scale isometrically or allometrically to egg weight (and the larval elements to larval weight) within and across species? And (iii), if scaling across species is not isometric, what are the evolutionary consequences in terms of reproductive effort relative to maternal body size?

\section{MATERIAL AND METHODS}

\section{Species, life histories, and sample collection}

The species selected represent a taxonomically varied sample of the European genera: Lasiommata megera (L., 1767), Pararge aegeria (L., 1758), Coenonympha pamphilus (L., 1758), C. glycerion (Borkhausen, 1788), Pyronia bathseba (Fabricius, 1793), P. cecilia (Vallantin, 1894), Melanargia lachesis (Hübner, 1790), Hipparchia alcyone (Dennis \& Schiffermüller, 1775), H. semele (L., 1758), H. statilinus (Hufnagel, 1766), H. fidia (L., 1767), and Kanetisa circe (Fabricius, 1775). Data on dry eggs of Melanargia russiae (Esper, 1783) and Satyrus actaea (Esper, 1780) from independent studies were incorporated for comparisons that did not require fresh egg weight. All the species studied have oligophagous larvae and use grasses (Grammineae) as host plants. However, they differ ecologically in that $P$. aegeria, C. pamphilus and L. megera are bi- or multivoltine, while the remaining species are univoltine. $P$. cecilia, $H$. fidia and $H$. statilinus are markedly xerophilous, while $P$. aegeria and $C$. glycerion are predominantly linked to moist habitats in the study area. $P$. bathseba, M. lachesis and $K$. circe drop their eggs among the vegetation instead of fixing them to grasses, like most other satyrines. Summer diapause occurs in the egg stage of $P$. bathseba and the first instar larvae of Melanargia spp. Satyrus actaea aestivate as pharate larvae within their egg shells.

All the insects originated from sites located within an area of $150 \mathrm{~km}$ around the city of Madrid (Spain). Female adults were either raised from larvae in the laboratory, or collected in the field as mating couples. The laboratory-reared larvae were provided with their local hosts (namely, Brachypodium spp., Stipa spp., Poa spp. and Festuca spp.; details in Munguira et al., 1997). When this was not possible, a standard mixture of Festuca rubra L., Poa annua, and P. pratensis L. was used, so that the larvae had the choice to select for hosts. In order to standardise female weights, they were weighed one day after mating. Since the effects of different temperature regimes on egg-laying and adult feeding rates of most of these satyrines are unknown, an effort was made to keep the ovipositing females under the most natural possible conditions. Mated females were kept in 11 transparent individual jars under natural temperature and photoperiod conditions, fed with a $30 \%$ sucrose water solution and provided with a tuft of grass to stimulate oviposition. The daily egg production of each female was divided into two sub-equal subsets, both of which were weighed to the nearest $0.001 \mathrm{mg}$. One subset was frozen overnight $\left(-30^{\circ} \mathrm{C}\right)$, desiccated $\left(60^{\circ} \mathrm{C}\right.$ for $\left.72 \mathrm{~h}\right)$ and then re-weighed to determine dry weight. The remaining subset was allowed to develop until eclosion $\left(23^{\circ} \mathrm{C}\right.$, photoperiod $\left.16 \mathrm{~L}: 8 \mathrm{D}\right)$, when the newly hatched larvae were treated as described for the eggs. The results from the daily subsets of eggs and larvae for each female were pooled. Elemental analyses of individual offspring or daily subsets were not possible because their dry weights were well below those required for elemental analyses (ca. $1.9 \mathrm{mg}$ ). Once pooled and homogenised, the egg and hatchling samples were again desic- 
TABLE 1. Mean fresh and dry weights of the eggs, larvae and females and realised fecundities $( \pm 1$ s.d.). $n=$ number of individuals; $n '=$ total number of eggs. The figures in the last row are the $F$ scores of a one-way ANOVAs on the egg and larval data with the species identity as the test variable $(\log$ transformed values; $* * *=P<0.001)$

\begin{tabular}{|c|c|c|c|c|c|c|c|}
\hline \multirow{2}{*}{ Species } & \multirow{2}{*}{ n (n') } & \multicolumn{2}{|c|}{ Eggs } & \multicolumn{2}{|c|}{ Larvae } & \multicolumn{2}{|c|}{ Adult females } \\
\hline & & fresh weight & dry weight & fresh weight & dry weight & weight (mg) & fecundity \\
\hline P. aegeria & $11(378)$ & $0.40 \pm 0.05$ & $0.08 \pm 0.01$ & $0.31 \pm 0.04$ & $0.05 \pm 0.01$ & $51.1 \pm 21.8$ & $134.5 \pm 28.2$ \\
\hline L. megera & $5(166)$ & $0.52 \pm 0.09$ & $0.10 \pm 0.02$ & $0.37 \pm 0.05$ & $0.08 \pm 0.01$ & $54.3 \pm 9.7$ & $169.2 \pm 53.3$ \\
\hline P. cecilia & $12(699)$ & $0.13 \pm 0.01$ & $0.05 \pm 0.01$ & $0.08 \pm 0.01$ & $0.03 \pm 0.01$ & $53.7 \pm 4.8$ & $412.0 \pm 217.8$ \\
\hline P. bathseba & $10(509)$ & $0.25 \pm 0.02$ & $0.09 \pm 0.01$ & $0.23 \pm 0.01$ & $0.07 \pm 0.01$ & $63.0 \pm 5.7$ & $188.8 \pm 64.8$ \\
\hline C. glycerion & $11(348)$ & $0.59 \pm 0.07$ & $0.13 \pm 0.02$ & $0.36 \pm 0.04$ & $0.09 \pm 0.01$ & $52.8 \pm 6.1$ & $102.3 \pm 64.5$ \\
\hline C. pamphilus & $22(782)$ & $0.26 \pm 0.03$ & $0.07 \pm 0.01$ & $0.19 \pm 0.02$ & $0.05 \pm 0.01$ & $35.2 \pm 8.8$ & $198.1 \pm 31.2$ \\
\hline H. semele & $15(550)$ & $0.30 \pm 0.04$ & $0.08 \pm 0.01$ & $0.21 \pm 0.03$ & $0.05 \pm 0.01$ & $139.6 \pm 26.8$ & $536.6 \pm 91.8$ \\
\hline H. alcyone & $10(284)$ & $0.67 \pm 0.04$ & $0.17 \pm 0.01$ & $0.52 \pm 0.03$ & $0.14 \pm 0.01$ & $204.4 \pm 8.5$ & $365.6 \pm 156.5$ \\
\hline H. fidia & $10(369)$ & $0.95 \pm 0.11$ & $0.24 \pm 0.03$ & $0.68 \pm 0.08$ & $0.21 \pm 0.03$ & $165.4 \pm 31.8$ & $217.7 \pm 98.1$ \\
\hline H. statilinus & $13(612)$ & $0.26 \pm 0.02$ & $0.07 \pm 0.01$ & $0.19 \pm 0.02$ & $0.05 \pm 0.01$ & $148.3 \pm 39.3$ & $588.4 \pm 167.3$ \\
\hline K. circe & $9(464)$ & $0.34 \pm 0.03$ & $0.11 \pm 0.01$ & $0.24 \pm 0.02$ & $0.07 \pm 0.01$ & $292.1 \pm 25.6$ & $665.6 \pm 223.2$ \\
\hline M. lachesis & $24(775)$ & $0.64 \pm 0.06$ & $0.20 \pm 0.02$ & $0.46 \pm 0.05$ & $0.14 \pm 0.01$ & $106.8 \pm 12.2$ & $173.7 \pm 96.9$ \\
\hline $\mathrm{F}_{11,152}$ & - & $312.16^{* * *}$ & $274.63^{* * *}$ & $278.33^{* * *}$ & $377.79 * * *$ & - & - \\
\hline
\end{tabular}

cated to constant weight and analysed by instantaneous dynamic combustion using an Elemental Perkin-Elmer 2400 Analyser. Given the small mass of an egg shell, its elemental composition was determined directly in only six species for which very large numbers of empty egg shells were available.

\section{General statistical treatment}

Unless otherwise stated, all the data analysed are weights in $\mathrm{mg}$, transformed to their decimal logarithms. The total carbon and nitrogen contents were calculated from the percentage composition and sample dry weight. The variable names are abbreviated as: $f=$ fresh weight, $d=$ dry weight, $w=$ water content, $C$ $=$ carbon and $N=$ nitrogen content, followed by the subscripts ${ }_{E}$ $=$ egg, ${ }_{L}=$ neonate larva and ${ }_{S}=$ egg shell. Throughout the text, means are given \pm 1 S.D. The potential specificity of each egg and larval trait was tested by ANOVA with species codes as the classification factor. Although this allows for a test of the general effects of the factor on each variable, several series of pairwise post-hoc tests are required to check for between-species differences in all traits. Therefore, to estimate the classificatory power of the variables (controlling for the general effects of egg size), a forward stepwise discriminant analysis was applied to the regressions' residuals for each variable on fresh egg weight. This is adequate for determining the explanatory power that an a priori classification factor (such as taxonomy) has on a set of interrelated quantitative variables (e.g., Johnson \& Wichern, 2002). The patterns of overall species similarity were determined by means of UPGMA agglomerative clustering based on Euclidean distances. Since all the variables were strongly correlated with egg size, cluster analysis was repeated using the residuals of the regressions of each variable on $f_{E}$. Pairwise comparisons between variables while controlling for the effects of a third factor (generally $f_{E}$ ), as well as the tests for the differences between the slopes of the linear regressions of two dependent variables, were evaluated using ANCOVA.

\section{Comparative analyses}

To override phylogenetic interdependence in the species means, inter-specific comparisons were performed on independent contrasts (Felsenstein, 1985; see Harvey \& Pagel, 1991; Starck, 1998). These were calculated using the program CON-
TRAST (Felsenstein, 2004); regressions of these values were forced through the origin (Felsenstein, 1985, 2004). The phylogenetic approach of Martin et al. (2000) was adopted after slight adaptation for the species studied, which involved substituting co-generic species for four species in the original cladogram (two Coenonympha, one Pyronia and one Hipparchia). Branch lengths (necessary to estimate the contrasts) were calculated using DNAML (Felsenstein, 2004) and the nucleotide sequences reported by Martin et al. (2000). For those branches leading to the substituted species, the lengths were set to the average distances between the closest pair of co-generic species in the reference cladogram. This option was more realistic than setting all lengths to the same value, as the method of independent contrasts is robust in terms of branch length accuracy (Martins \& Garland, 1991). An attempt was made to detect correlations between the egg and larval composition variables and several life history or environmental factors, i.e.: 1 - voltinism (univoltine/multivoltine), 2 - xerophily (hygrophilous/xerophilous), 3 - egg laying mode (eggs fixed/eggs dropped), 4 summer diapause in the egg stage, 5 - diapause in the first instar larval stage, 6 - number of days spent in the egg stage under natural conditions (modal value), 7 - adult female weight and 8 - female fecundity. These egg and larval variables were used to estimate the independent contrasts, except that variables 1 to 5 were coded as categorical (which resulted in a lower number of contrasts). All the contrasts were first regressed on the fresh egg contrasts and the residuals saved (these should be independent of the effects of overall egg size). The residuals were then analysed by forward stepwise regression using the GRM (General Regression Models) module in Statistica (Statsoft, 2004), which allows the combination of continuous and categorical variables.

\section{RESULTS}

\section{Specificity and similarity of the egg and neonate composition}

The egg and neonate composition data are shown in Tables $1-2$. The $\mathrm{C}: \mathrm{N}$ ratios were lower for larvae than for eggs, and for egg chorions than egg contents (Table 2). The factor "species" had a significant effect on all 
TABle 2. Mean $\mathrm{C}$ and $\mathrm{N}$ contents (\% of dry weight) and average $\mathrm{C}: \mathrm{N}$ ratios for the eggs, neonate larvae and egg shells. Whole egg and larval sample sizes are as in Table 1 except for $S$. actaea $(\mathrm{n}=2)$. The egg shell $\mathrm{C}$ and $\mathrm{N}$ percentages are from pooled egg shell samples collected from a large number of empty egg shells from independent specimens $(n=1$, except for $H$. alcyone and $H$. fidia where $n=2$ ). Last row is of the $F$ values of a one-way ANOVA of each variable with species as the independent variable (** $=$ $P<0.001, * * *=P<0.0001)$.

\begin{tabular}{|c|c|c|c|c|c|c|c|c|c|}
\hline \multirow{2}{*}{ Species } & \multicolumn{3}{|c|}{ Whole egg } & \multicolumn{3}{|c|}{ Larva } & \multicolumn{3}{|c|}{ Egg shell } \\
\hline & $\% \mathrm{C}$ & $\% \mathrm{~N}$ & $\mathrm{C}: \mathrm{N}$ ratio & $\% \mathrm{C}$ & $\% \mathrm{~N}$ & $\mathrm{C}: \mathrm{N}$ ratio & $\% \mathrm{C}$ & $\% \mathrm{~N}$ & $\mathrm{C}: \mathrm{N}$ ratio \\
\hline P. aegeria & $52.0 \pm 0.5$ & $8.3 \pm 0.2$ & $7.29 \pm 0.12$ & $48.3 \pm 1.6$ & $10.9 \pm 0.4$ & $5.16 \pm 0.15$ & - & - & - \\
\hline L. megera & $53.0 \pm 0.1$ & $8.3 \pm 0.1$ & $7.46 \pm 0.16$ & $50.8 \pm 0.3$ & $10.3 \pm 0.3$ & $5.74 \pm 0.19$ & - & - & - \\
\hline P. cecilia & $57.9 \pm 1.1$ & $7.3 \pm 0.6$ & $9.28 \pm 0.12$ & $54.9 \pm 1.4$ & $9.4 \pm 0.7$ & $6.82 \pm 0.14$ & - & - & - \\
\hline P. bathseba & $57.3 \pm 0.9$ & $8.8 \pm 0.5$ & $7.66 \pm 0.13$ & $54.1 \pm 1.1$ & $9.9 \pm 0.5$ & $6.38 \pm 0.15$ & - & - & - \\
\hline C. glycerion & $51.2 \pm 0.7$ & $8.4 \pm 0.3$ & $7.08 \pm 0.12$ & $48.4 \pm 0.9$ & $10.6 \pm 0.8$ & $5.38 \pm 0.15$ & - & - & - \\
\hline C. pamphilus & $57.8 \pm 0.9$ & $7.1 \pm 0.3$ & $9.54 \pm 0.09$ & $56.1 \pm 1.1$ & $7.9 \pm 0.6$ & $8.31 \pm 0.11$ & - & - & - \\
\hline H. semele & $55.2 \pm 1.4$ & $8.1 \pm 0.6$ & $7.99 \pm 0.11$ & $51.4 \pm 2.2$ & $10.9 \pm 0.6$ & $7.10 \pm 0.14$ & 48.3 & 11.5 & 4.88 \\
\hline H. alcyone & $54.9 \pm 1.4$ & $7.5 \pm 0.2$ & $8.55 \pm 0.13$ & $54.4 \pm 0.6$ & $8.9 \pm 0.2$ & $7.12 \pm 0.15$ & $49.8 \pm 0.1$ & $12.9 \pm 0.1$ & $4.49 \pm 0.04$ \\
\hline H. fidia & $58.4 \pm 0.3$ & $6.8 \pm 0.4$ & $10.03 \pm 0.13$ & $57.2 \pm 1.3$ & $7.8 \pm 0.7$ & $8.65 \pm 0.15$ & $51.6 \pm 0.1$ & $12.3 \pm 0.3$ & $4.90 \pm 0.12$ \\
\hline H. statilinus & $55.9 \pm 0.9$ & $7.3 \pm 0.1$ & $8.89 \pm 0.11$ & $54.5 \pm 0.8$ & $8.9 \pm 0.2$ & $5.48 \pm 0.13$ & 52.8 & 10.8 & 5.69 \\
\hline K. circe & $57.4 \pm 1.1$ & $7.9 \pm 0.3$ & $8.49 \pm 0.13$ & $54.6 \pm 1.1$ & $9.3 \pm 0.6$ & $6.89 \pm 0.16$ & 50.6 & 14.2 & 4.16 \\
\hline M. lachesis & $57.8 \pm 0.5$ & $7.6 \pm 0.3$ & $8.94 \pm 0.09$ & $56.9 \pm 1.1$ & $7.7 \pm 0.3$ & $8.66 \pm 0.10$ & 51 & 13.3 & 4.46 \\
\hline S. actaea & $53.4 \pm 0.3$ & $9.3 \pm 0.3$ & $6.39 \pm 0.21$ & $48.0 \pm 0.1$ & $11.9 \pm 0.1$ & $4.50 \pm 0.01$ & 48.6 & 14.7 & 3.87 \\
\hline M. russiae & - & - & - & - & - & - & 52.1 & 11.8 & 5.16 \\
\hline $\mathrm{F}_{11,152}$ & $83.74 * * *$ & $2.86^{* *}$ & $63.62 * * *$ & $69.08 * * *$ & $71.76^{* * *}$ & $92.2 * * *$ & - & - & - \\
\hline
\end{tabular}

variables when these were compared as percentages of the total fresh or dry weight. Since it was not a priori known whether or not percentages (simple ratios) were suitable for comparison (because of the possibility of allometry), ANCOVA analyses of the egg variables (with $f_{E}$ as the covariate) and of the larval variables (with $f_{L}$ as covariate) were performed; the effects remained significant (Table 3). Thus all traits tended to be specific fea-
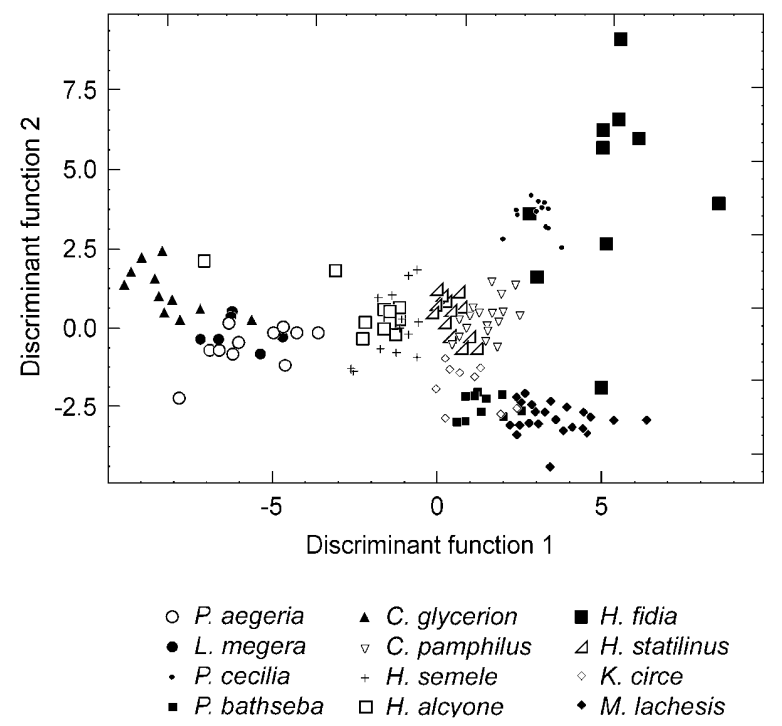

Fig. 1. Plot of the canonical scores of the two first functions obtained from forward stepwise discriminant analysis. The input data were the residuals of regressions of each variable on egg weight; hence the results can be interpreted as independent of egg size. tures, although this does not mean that every trait differed between each pair of species. The discriminant analysis based on residuals (thus excluding $f_{E}$ and its main effect in the other traits) was useful to summarise the main relations: the first two factors explained $82.4 \%$ of the variation $\left(\chi^{2}=86.99,21\right.$ d.f., $\left.P<0.0001\right)$, with the first discriminant function being primarily associated with $C_{e}$, $C_{L}, d_{E}$ and $d_{L}$, and the second with $N_{E}, d_{E}$ and $C_{E}$, (Fig. 1). This combination successfully classified $92 \%$ of the cases, although less than $90 \%$ (55\% to $86 \%$ ) for $L$. megera, $H$. fidia, $H$. statilinus and $K$. circe.

\section{Phylogeny and ecology as potential explanations for the egg and larval features}

The species overall similarity based on the mean egg and neonate values for all variables, as well as that derived from the residual (size-independent) values, were inconsistent with the phylogenetic hypothesis (Fig. 2; the Spearman rank correlations between each distance matrix and that inferred from molecular data were, respectively $r_{s}=-0.11, P=0.36$, and $\left.r_{s}=0.01, P=0.94\right)$.

The stepwise regression of the contrasts from the environmental or biological variables on egg and neonate features (after controlling for the effects of fresh egg weight) produced no significant results for the duration of the egg stage, pattern of voltinism, diapause in the first larval instar, fecundity and female weight (none of the offspring features was selected for the model). Just three other variables were explained by at least one egg or larval trait: xeric/moist habitat was related to high egg $\mathrm{C}: \mathrm{N}$ ratios (highest ratios in most xeric species, $r=0.64, P<0.05,9$ d.f.), presence of diapause in the egg stage with $N_{L}(r=$ $0.92, P<0.01,5$ d.f.; the relationship with $N_{E}$ was posi- 
TABle 3. Summary of the results from a series of one-way independent ANCOVAs of the weights to determine whether there are significant inter-specific differences in the egg and larval variables, after controlling for general size effects. "Species" was the independent variable in all instances. In analysis (A), $d_{E}$ and $f_{L}$ were tested with fresh egg weight $\left(f_{E}\right)$ as the covariable. In analysis (B), $d_{L}, d_{S}, C_{E}, N_{E}, C_{L}$ and $N_{L}$ were the response variables and dry egg weight $\left(d_{E}\right)$ the covariable. The $F$ values shown denote the effects of the covariable and the remaining effect of each test variable. All $F$ values were significant at $P<0.00001$; sample sizes $(n)$ as in Table 1 .

\begin{tabular}{lccc}
\hline & Variable & $\begin{array}{c}\text { Covariate, } \\
\text { d.f. }=1\end{array}$ & $\begin{array}{c}\text { Species, } \\
\text { d.f. }=11\end{array}$ \\
\hline (A) Covariate $=f_{E}$ & $d_{E}$ & $F=247.55$ & $F=91.7$ \\
& $f_{L}$ & $F=189.12$ & $F=23.9$ \\
(B) Covariate $=d_{E}$ & $d_{L}$ & $F=31.95$ & $F=20.91$ \\
& $d_{S}$ & $F=23.39$ & $F=17.25$ \\
& $C_{E}$ & $F=6219.5$ & $F=106.78$ \\
& $N_{E}$ & $F=839.9$ & $F=40.43$ \\
& $C_{L}$ & $F=22.85$ & $F=32.23$ \\
& $N_{L}$ & $F=28.35$ & $F=21.57$ \\
\hline
\end{tabular}

tive but not significant, partial $r=0.63, P>0.05)$ and egg dropping with $N_{E}$ and $C_{L}$ (partial correlations, respectively $r=0.98$ and $r=0.92$, both $P<0.01$; whole model regression $r=0.99, P<0.001,7$ d.f.).

\section{Intra-specific allometry}

Within each species, all the variables were highly and significantly correlated to $f_{E}$ (Table 4 ; as expected, the weights of the total $\mathrm{C}$ and $\mathrm{N}$ contents were highly correlated with the weight of dry matter, and are not presented for simplicity). $f_{L}$ was related to $f_{E}$ with slopes of between 0.5 and 1.2. In P. bathseba and C. pamphilus $d_{E}$ scaled to $f_{E}$ with slopes significantly below 1.00, implying that comparatively more water is invested in the largest eggs of these species. The extent of the egg size-dependent variation in the amount of water invested per neonate

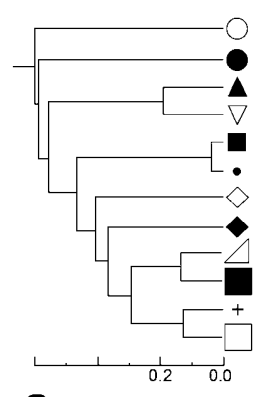

a

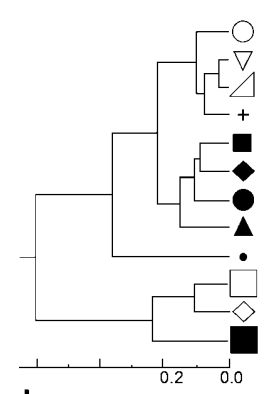

b

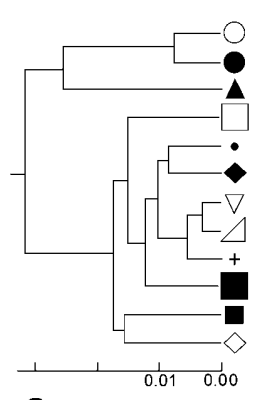

C
Fig. 2. $\mathrm{A}=$ Phylogenetic relations among the species analysed, adapted from Martin et al. (2000). B, C = Overall similarity of the species based on the composition of the egg and first instar larva (Euclidean distances, UPGMA procedure, data from Tables 1 and 2). $\mathrm{B}=$ based on the log-transformed values of all the variables, $\mathrm{C}=$ general egg size effects excluded (based on the residuals of regressions of each variable on egg weight). Species symbols as in Fig. 1. Branch lengths are arbitrary non-metric units.

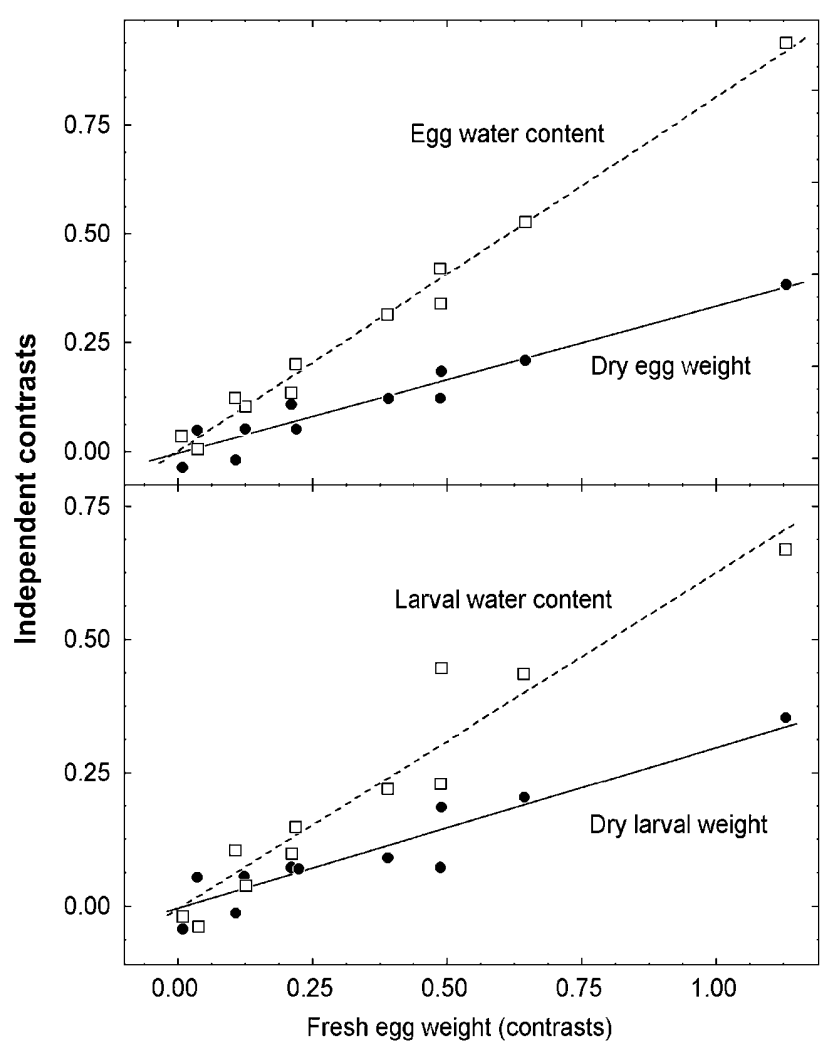

Fig. 3. Inter-specific scaling of dry matter content and absolute water content to fresh egg weight, based on independent contrasts (statistics in Table 6).

larva and in the ratio of egg shell to dry larval weight can be deduced from Table 4. Since the non-larval proportion of egg dry matter is largely the chorion weight, the slope of dry larval weight to dry egg weight of significantly less than 1.00 in two species indicates a positive allometric investment in the egg shell. Similarly, the proportion of dry matter to fresh larval weight was proportionally lower in the largest larvae of just one species, i.e. M. lachesis.

$\mathrm{N}$ scaled with $\mathrm{C}$ with exponents close to 1.00 in the eggs and larvae of most of the species (Table 5).

\section{Inter-specific allometry}

Correlations based on the independent contrasts demonstrated a strong association between each trait and $f_{E}$ (Table 6, Fig. 3). ANCOVA tests for the between-stage differences in the slopes relative to fresh egg weight showed no significant differences for dry weight $\left(F_{1,18}=\right.$ $0.23, P=0.63), \mathrm{C}$ content $\left(F_{1,18}=0.21, P=0.66\right)$ and $\mathrm{N}$ content $\left(F_{1,18}=0.01, P=0.97\right)$, hence the egg data reasonably represented the proportion of $\mathrm{C}, \mathrm{N}$ and dry weight invested in neonates. In terms of egg mass, the average fecundity represented $113 \%$ of the female fresh body weight and the dry weight of the egg contents from 21 to $40 \%$ of female's weight. The total investment in fresh egg weight was nearly isometric with female weight (slope $=0.95, r=0.98, P<0.00001, n=11$ ) across independent contrasts, as well as on the basis of the logtransformed species data means $(r=0.98, P<0.00001, n$ $=12$; regression equation: $\log ($ egg mass $)=-0.517+$ 
TABLE 4. Intra-specific scaling relations of dry egg weight, dry larval weight and fresh larval weight to fresh egg weight, and of dry larval weight to both, fresh larval and dry egg weights. Only the correlations $(r)$ and values of the slopes $(b)$ are given (slopes from non-significant regressions not presented). ${ }^{a}=$ The $95 \%$ confidence limits of the slope do not include $b=1.00$. The Bonferroni correction for multiple independent tests was applied to each independent within-species test. The overall effects for the pooled data (test for within-species level in hierarchically nested regression) are given in the last row. ${ }^{*}=P<0.05,{ }^{* *}=P<0.01, * * *=P<$ $0.001, \mathrm{~ns}=P>0.05$. Sample sizes as in Table 1 .

\begin{tabular}{|c|c|c|c|c|c|c|c|c|c|c|}
\hline Dependent: & $d_{E}$ & & $d_{L}$ & & $f_{L}$ & & $d_{L}$ & & $d_{L}$ & \\
\hline Predictor: & $f_{E}$ & & $f_{E}$ & & $f_{E}$ & & $f_{L}$ & & $d_{E}$ & \\
\hline Species & $b$ & (r) & $b$ & $(r)$ & $b$ & (r) & $b$ & (r) & $b$ & (r) \\
\hline P. aegeria & - & $(0.65 \mathrm{~ns})$ & - & $(0.26 \mathrm{~ns})$ & 0.95 & $(0.92 * * *)$ & - & $(0.39 \mathrm{~ns})$ & - & $(0.11 \mathrm{~ns})$ \\
\hline L. megera & - & $(0.81 \mathrm{~ns})$ & 0.83 & $(0.99 * * *)$ & 0.95 & $(0.99 * * *)$ & 0.85 & $(0.96 * *)$ & - & $(0.82 \mathrm{~ns})$ \\
\hline P. cecilia & 0.97 & $(0.87 * * *)$ & - & $(0.56 \mathrm{~ns})$ & 1.04 & $(0.80 * *)$ & - & $(0.58 \mathrm{~ns})$ & - & $(0.59 \mathrm{~ns})$ \\
\hline P. bathseba & $0.67^{\mathrm{a}}$ & $(0.91 * * *)$ & 0.41 & $(0.71 * *)$ & $0.63^{\mathrm{a}}$ & $(0.95 * * *)$ & - & $(0.72 \mathrm{~ns})$ & $0.53^{a}$ & $(0.75 *)$ \\
\hline C. glycerion & 0.84 & $(0.78 * *)$ & - & $(0.50 \mathrm{~ns})$ & $0.64^{\mathrm{a}}$ & $(0.79 * *)$ & 0.72 & $(0.81 *)$ & - & $(0.28 \mathrm{~ns})$ \\
\hline C. pamphilus & $0.75^{\mathrm{a}}$ & $(0.80 * * *)$ & - & $(0.10 \mathrm{~ns})$ & $0.54^{\mathrm{a}}$ & $(0.50 *)$ & - & $(0.33 \mathrm{~ns})$ & - & $(0.16 \mathrm{~ns})$ \\
\hline H. alcyone & 0.80 & $(0.86 * *)$ & - & $(0.55 \mathrm{~ns})$ & 0.80 & $(0.78 *)$ & 0.86 & $(0.85 * *)$ & - & $(0.59 \mathrm{~ns})$ \\
\hline H. semele & 0.68 & $(0.71 * *)$ & $0.47^{\mathrm{a}}$ & $(0.73 * *)$ & 0.91 & $(0.68 * *)$ & - & $(0.26 \mathrm{~ns})$ & - & $(0.50 \mathrm{~ns})$ \\
\hline H. statilinus & 0.95 & $(0.84 * * *)$ & - & $(0.36 \mathrm{~ns})$ & 1.17 & $(0.93 * * *)$ & 0.89 & $(0.51 *)$ & - & $(0.61 \mathrm{~ns})$ \\
\hline H. fidia & 0.68 & $(0.72 *)$ & 0.88 & $(0.81 * *)$ & 0.90 & $(0.87 * * *)$ & - & $(0.52 \mathrm{~ns})$ & 0.93 & $(0.80 *)$ \\
\hline$K$. circe & - & $(0.72 \mathrm{~ns})$ & - & $(0.55 \mathrm{~ns})$ & 0.72 & $(0.84 * *)$ & - & $(0.54 \mathrm{~ns})$ & 0.84 & $(0.80 *)$ \\
\hline M. lachesis & 1.10 & $(0.96 * * *)$ & 0.63 & $(0.72 * * *)$ & 0.89 & $(0.74 * * *)$ & $0.51^{\mathrm{a}}$ & $(0.70 * *)$ & $0.56^{\mathrm{a}}$ & $(0.74 * * *)$ \\
\hline Overall & \multicolumn{2}{|c|}{$\mathrm{F}_{12,140}=23.04 * * *$} & \multicolumn{2}{|c|}{$\mathrm{F}_{12,140}=4.44 * * *$} & \multicolumn{2}{|c|}{$\mathrm{F}_{12,140}=16.18 * * *$} & \multicolumn{2}{|c|}{$F_{12,140}=4.67 * * *$} & \multicolumn{2}{|c|}{$\mathrm{F}_{12,140}=5.14 * * *$} \\
\hline
\end{tabular}

$0.980 \cdot \log ($ female weight). The slope of accumulated $\mathrm{N}$ content relative to female weight was steeper than that for C content $\left(F_{2,18}=23.47, P<0.0001\right.$; Fig. 4$)$.

TABLE 5. Intra-specific scaling relations between total $\mathrm{C}$ and $\mathrm{N}$ contents of the eggs and the newly hatched larvae. Slope $(b)$ and correlation $(r)$ from regressions of log-transformed total weights of $\mathrm{N}$ on that of $\mathrm{C}$ in the eggs and larvae. The $95 \%$ confidence limits of the slope include 1.00 in all instances, indicating that isometry cannot be discarded in these two life stages. $*=P<0.05, * *=P<0.01, * * *=P<0.001, \mathrm{~ns}=P>0.05$ (levels of significance adjusted by using the Bonferroni correction for multiple independent comparisons). Overall effects on the pooled data (test for the within-species level) are presented in the last row. Sample sizes are as in Table 1.

\begin{tabular}{|c|c|c|c|c|}
\hline \multirow{3}{*}{ Species } & \multicolumn{4}{|c|}{ Regression } \\
\hline & \multicolumn{2}{|c|}{$N_{E}$ on $C_{E}$} & \multicolumn{2}{|c|}{$N_{L}$ on $C_{L}$} \\
\hline & $b$ & (r) & $b$ & (r) \\
\hline P. aegeria & 0.98 & $(0.93 * * *)$ & 0.74 & $(0.85 * *)$ \\
\hline L. megera & 0.96 & $(0.99 * * *)$ & 0.93 & $(0.99 * * *)$ \\
\hline P. cecilia & 0.95 & $(0.64 *)$ & 0.66 & $(0.64 *)$ \\
\hline P. bathseba & - & $(0.44 \mathrm{~ns})$ & - & $(0.10 \mathrm{~ns})$ \\
\hline C. glycerion & 0.92 & $(0.98 * * *)$ & 1.07 & $(0.70 *)$ \\
\hline C. pamphilus & 0.88 & $(0.88 * * *)$ & 0.96 & $(0.85 * * *)$ \\
\hline H. alcyone & 0.94 & $(0.75 *)$ & 1.10 & $(0.92 * * *)$ \\
\hline H. semele & 1.09 & $(0.91 * * *)$ & 0.80 & $(0.62 *)$ \\
\hline H. statilinus & 0.97 & $(0.97 * * *)$ & 0.96 & $(0.98 * * *)$ \\
\hline H. fidia & 1.26 & $(0.94 * * *)$ & - & (0.61 ns) \\
\hline K. circe & 1.08 & $(0.94 * * *)$ & 0.81 & $(0.79 * *)$ \\
\hline M. lachesis & 1.07 & $(0.96 * * *)$ & 1.01 & $(0.89 * * *)$ \\
\hline Overall & \multicolumn{2}{|c|}{$\mathrm{F}_{12,140}=52.53 * * *$} & \multicolumn{2}{|c|}{$\mathrm{F}_{12,140}=24.12 * * *$} \\
\hline
\end{tabular}

\section{DISCUSSION AND CONCLUSIONS}

The elemental composition of satyrine eggs is broadly similar to that reported for a few other Lepidoptera, and the $\mathrm{C}: \mathrm{N}$ ratios conform to those of five nymphalid and pierid butterflies (Chauvin \& Vannier, 1997; Fischer et al., 2004; O'Brien et al., 2004). Within these ranges, the absolute and relative egg and neonate compositions are highly species-specific. This is especially meaningful given that rearing conditions during the larval stage and temperatures during oviposition were not standardised. This may of course raise some criticism concerning one part of the results (for instance, temperature is known to affect egg size: Fischer et al., 2003). Accordingly, the interpretation of the results has to be conservative. Even so, species with different ecologies and adult flight periods are likely to have different optima for reproduction, the reason why this experimental design was adopted.

TABLE 6. Inter-specific relations between egg weight $\left(f_{E}\right)$ and other variables, based on independent contrasts and regression through the origin. $(* * *=P<0.001)$.

\begin{tabular}{lcc}
\hline \multirow{2}{*}{ Dependent variable } & \multicolumn{2}{c}{ Regression of $f_{E}$} \\
\cline { 2 - 3 } & Slope & $(r)$ \\
\hline Larval weight $\left(f_{L}\right)$ & 0.83 & $(0.98 * * *)$ \\
Dry egg weight $\left(d_{E}\right)$ & 0.33 & $(0.98 * * *)$ \\
Dry larval weight $\left(d_{L}\right)$ & 0.30 & $(0.97 * * *)$ \\
Egg C content $\left(C_{E}\right)$ & 0.19 & $(0.97 * * *)$ \\
Larval C content $\left(C_{L}\right)$ & 0.18 & $(0.95 * * *)$ \\
Egg N content $\left(N_{E}\right)$ & 0.03 & $(0.95 * * *)$ \\
Larval N content $\left(N_{L}\right)$ & 0.03 & $(0.97 * * *)$ \\
\hline
\end{tabular}




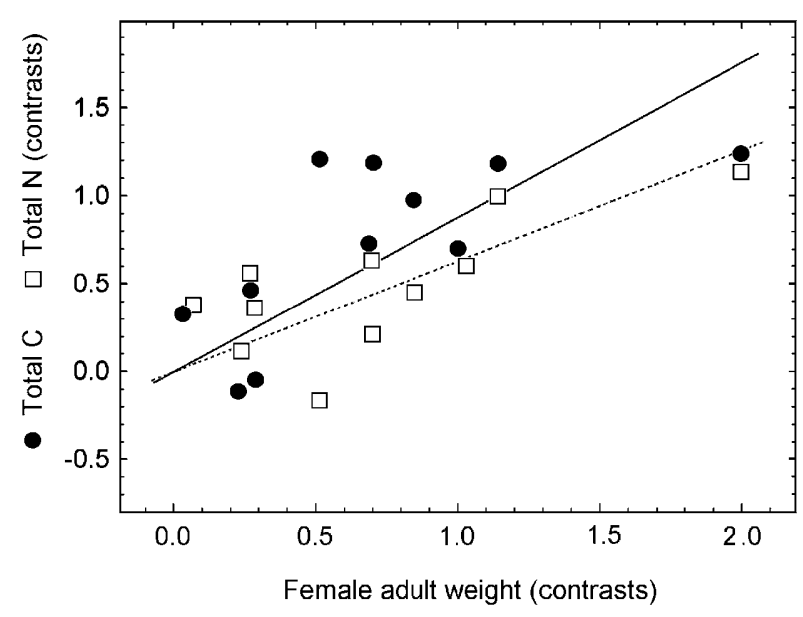

Fig. 4. Inter-specific scaling of total $\mathrm{C}$ and $\mathrm{N}$ contents to female body weight, based on a set of 11 independent contrasts. $\mathrm{C}-$ dots and solid line (slope $=0.87, r=0.89, P<0.0001), \mathrm{N}-$ squares and dashed line (slope $=0.63, r=0.91, P<0.0001$ ).

The similarities across species have no obvious phylogenetic explanation, which might be explained by fast rates of evolution associated with ecological adaptation. In fact, some characteristics of the habitat are likely to have selected for egg size or fecundity in European satyrines (Karlsson \& Wiklund, 2005). However, the evidence concerning the egg or neonate larval features in this study is poor, and restricted to three features: $1-$ xeric species lay eggs with comparatively high $\mathrm{C}: \mathrm{N}$ ratios, 2 - neonate larvae of species that undergo diapause in the egg stage have comparatively more nitrogen, and 3 - species whose females drop the eggs invest proportionally more nitrogen per egg, and more carbon per mg of larval weight. Due to the small number of species investigated, only the third correlation was relatively robust. Moreover, the interpretation of these results is not straightforward. Insect eggs are reservoirs of lipoproteins, and proteins account for ca. $95 \%$ of the egg dry mass in Lepidoptera (Fehrenbach, 2003). A high C content may well represent high investment in energy-storage lipo-proteins in insect eggs (Cunningham et al., 2001; Forte et al., 2002), but since the larval exoskeleton is rich in chitin (a polysaccharide) the shift in $\mathrm{C}: \mathrm{N}$ ratio between eggs and larvae may only indicate structural differences.

High $\mathrm{C}: \mathrm{N}$ ratios in the xerophylic species suggest some degree of physiological adaptation to water loss, a predictable effect of dry habitats. Karlsson \& Wiklund (1985) described species-specific patterns of egg resistance to desiccation in Swedish satyrines, which fitted the typical species habitats (eggs of species associated with moist habitats survived worst in dry conditions). Among the species studied, the most extreme xerophilous (e.g., $H$. fidia, $H$. statilinus, $P$. cecilia) differ by an almost tenfold variation in egg weight and do not have particularly thick chorions (García-Barros, 1994; García-Barros \& Martín, 1995). Fruit fly larvae from an experimental population selected for resistance to desiccation tended to store energy predominantly as glycogen, which is associated with water, rather than lipids (Chippendale et al.,
1998; Djawdan et al., 1998; a short review is given by Williams et al., 2005), which would lead to a C : N increase comparable to the one reported here. Since there were no other differences e.g., in the dry egg or larval weights, which would denote different proportions of water, it is likely that adaptation to dehydration in the egg stage, normally lasting less than one month in the species studied, is achieved by means of physiological rather than morphological specialisation.

The simplest explanation for the association between a high larval $\mathrm{N}$ content and egg diapause is that excreted $\mathrm{N}$ accumulated in neonate larvae. Most products of embryonic metabolism are probably present in neonate larvae: late stage embryos ingest the remains of embryonic membranes and yolk (Kobayashi et al., 2003); during and after eclosion, the neonates eat part of the chorion. However, it is not clear why the content of nitrogen in excreta should be the lowest in eggs with direct development (diapause is certainly long lasting, but the metabolic activity is lower). Moreover, a similar relationship (positive, although non significant) was found between egg diapause and the relative amount of nitrogen in the eggs. Thus, a more complex hypothesis, e.g., a higher nitrogen investment in larval structures, should not be completely discounted.

Finally, the differences found in the egg-dropping species might reflect structural differences. The chorion of several egg dropping satyrines has a thick lamellar layer (endochorion, or C3 layer: Hinton, 1981; Fehrenbach, 2003), which is also present in the non egg-dropping Satyrus spp. (García-Barros \& Martín, 1995; Jutzeler \& De Bros, 1996). This layer contains a high concentration of structural proteins (Fehrenbach, 2003 and references therein), which might function as a passive defence. This would imply an adaptive investment of nitrogen in nonlarval structures. In fact, the egg chorion contains higher proportions of nitrogen than the eggs and larvae (perhaps not surprisingly, newly hatched caterpillars of most Lepidoptera eat the egg shell immediately after eclosion). This is not an expensive investment when a comparatively light egg shell is produced, but it should be noted that the average egg shell accounts for $27.6 \%$ of the egg dry matter in the species analysed (estimated from the difference between the egg and larval dry weights in Table 1). Further work is required to assess the role of the various materials in the shell, as well as to determine their possible physiological costs for the female.

The within-species scaling relations are of interest since neonate larval size is often correlated with first instar larval survival within species of Lepidoptera (Nakasuji \& Kimura, 1984; Torres-Vila \& Rodríguez-Molina, 2002), but the reasons for this are not clear. Satyrine neonate larval size scales with egg size in an either allometric or nearly isometric mode, depending on the species. The same holds for the relationship between neonatal weight and egg weight: although egg size is correlated with neonate size, the larvae hatching from larger eggs were proportionally heavier than those from small eggs in some species, while no evidence for this was found in other 
species. Accordingly, neonatal size might determine first instar larval fitness indirectly, to different degrees in each species (depending on the specific scaling of the key element to egg weight). This may explain those cases where there is no relationship between neonate size and survival (cf. Karlsson \& Wiklund, 1984, 1985).

There is a roughly isometric relationship between the $\mathrm{C}$ and $\mathrm{N}$ contents of the eggs and larvae of the species studied, thus simple $\mathrm{C}$ : $\mathrm{N}$ ratios can be regarded as broadly size-independent and can be used in comparative studies. Because such ratios tend to be species-specific and independent of egg size, it follows that they must be important for functional reasons. One consequence is that, when either $\mathrm{C}$ or $\mathrm{N}$ supplies are limited, there should be a proportional reduction in the other component. This deserves further study in butterflies, where the sources of intraspecific variation in egg size include maternal age (Wiklund \& Persson, 1983; Wiklund \& Karlsson, 1984; Karlsson, 1987; Roff, 2002; Boggs, 2003) and environmentally induced plasticity (Nakasuji \& Kimura, 1984; Fox \& Czesak, 2000; Fischer \& Fiedler, 2001). For instance, female-age dependent reduction in egg weight should result from a depletion in the nitrogen resources rather than in hydrocarbons (the former are not replenished by adult feeding: Wheeler, 1996; Boggs, 1997, 2003; O'Brien et al., 2002, 2004). Thus in butterflies, the size of the eggs should decrease as one of the two nutrients becomes scarce, rather than show a shift in the $\mathrm{C}: \mathrm{N}$ ratio (as reported for parasitic wasps: Rivero et al., 2001; Giron \& Casas, 2003; cf. Fischer et al., 2004, and O'Brien et al., 2004 for butterflies). For similar reasons, differential survival of comparatively larger eggs is more likely to be due to the relative investments in water, dry weight, or egg shell mass rather than fresh egg weight (as suggested by Fischer et al., 2003) or the $\mathrm{C}: \mathrm{N}$ ratio.

Across-species analyses demonstrated a non-isometric scaling of $\mathrm{C}$ to $\mathrm{N}$ content in the eggs and neonate larvae, as well as an increasing ratio of water content to dry weight with increase in egg size. Unlike within-species, the proportional investment in nitrogen increased with adult body size. It is concluded that: (1) egg size and egg elemental composition have rarely evolved independently of each other, unless other life traits (e.g., adult size, feeding ecology) were modified; (2) in agreement with the assumption that the nitrogen reserves are far less flexible than those of carbon, the total nitrogen investment associated with increase in egg size is comparatively conservative; (3) selection for reduced egg size should not only result in a lower absolute amount of $\mathrm{N}$ invested per egg, but also in a higher proportion of $\mathrm{N}$ (i.e., a lower $\mathrm{C}: \mathrm{N}$ ratio) in the egg; and (4) females of the largest species appear to invest comparatively higher relative amounts of amino acids into their offspring.

Frequently, measures of the reproductive effort of animals scale to body weight hyperallometrically (slope > $1.0)$ within species, and hypoallometrically (slope $<1.0$ ) between species (Koztowski et al., 2003). It is thus surprising that the inter-specific relationship between these traits was nearly isometric in satyrines, revealing an asso- ciation between large body size and enhanced fecundity. This is consistent with evidence from comparative studies based on a broad taxonomic selection of butterfly species (García-Barros, 2000). Interestingly, if the results can be interpreted as evolutionary base-lines, then the trend towards decreasing egg size coupled to constant adult size would indicate that smaller eggs should be supplied with a higher proportion of nitrogen compounds. This hypothesis provides an adaptive explanation for small egg size.

In comparison to other life stages, the evolutionary interpretation of the features of eggs is complicated by the composite (maternal plus offspring) nature of the selection acting on egg characters (Rose \& Bradley, 1998; Fox $\&$ Czesak, 2000). However, the results indicate that further insights into insect reproductive strategies would greatly benefit from more data on the most simple aspects of the composition of eggs and first instar larvae.

ACKNOWLEDGEMENTS. I am thankful to P. Torres for his assistance with the elemental analyses, and to X. Bellés, K. Fischer and B. Karlsson, for valuable comments at different stages of this work. Parts of this study were funded by the Spanish Ministry for Education and Science (MEC: PB94-0173).

\section{REFERENCES}

Anger K., Moreira G.S. \& Ismael D. 2002: Comparative size, biomass, elemental composition $(\mathrm{C}, \mathrm{N}, \mathrm{H})$, and energy concentration of caridean shrimp-eggs. Invert. Reprod. Dev. 42: 83-93

Arms K., Feeny P. \& Lederhouse R.C. 1974: Sodium: stimulus for puddling behaviour by tiger swallowtails butterflies, Papilio glaucus. Science 185: 372-374.

BAur A. \& BAur B. 1998: Altitudinal variation in size and composition of eggs in the land snail Arianta arbustorum. Can. J. Zool. 76: 2067-2074.

Beck J., Mühlenberg E. \& Fiedler K. 1999: Mud-puddling behaviour in tropical butterflies: in search of proteins or minerals? Oecologia 119: 140-148.

BERRIGAN D. 1991: The allometry of egg size and number in insects. Oikos 60: 313-321.

BogGs C.L. 1997: Dynamics of reproductive allocation from juvenile and adult feeding: Radiotracer studies. Ecology 78: 192-202.

Boggs C.L. 2003: Environmental variation, life histories, and allocation. In Boggs C.L., Watt W.B. \& Ehrlich P.R. (eds): Butterflies. Ecology and Evolution Taking Flight. University of Chicago Press, Chicago, pp. 185-206.

Boggs C.L. \& DAU B. 2004: Resource specialization in puddling Lepidoptera. Environ. Entomol. 33: 1020-1024.

Boggs C.L. \& Ross C.L. 1993: The effect of adult food limitation on the life history traits in Speyeria mormonia (Lepidoptera: Nymphalidae). Ecology 74: 433-441.

Chauvin G. \& VAnNier G. 1997: Supercooling capacity of Tineola bisselliella (Hummel): Its implication for disinfestation. J. Stor. Prod. Res. 33: 283-287.

Chippendale A.K., Gibbs A.G., Sheik M., Yee K.J., Duawdan M., Bradley T.J. \& Rose M.R. 1998: Resource acquisition and the evolution of stress resistance in Drosophila melanogaster. Physiol. Zool. 71: 584-594.

Cunningham M., Gonzalez A., Dreon M., Castro D. \& Pollero R. 2001: Lipid and protein composition at different develop- 
mental stages of Pediculus capitis De Geer 1778. J. Insect Parasitol. 87: 1251-1254.

Duawdan M., Chippendale A.K., Rose M.R. \& Bradley T.J. 1998: Metabolic reserves and evolved stress resistance in Drosophila melanogaster. Physiol. Zool. 71: 584-594.

FAIRBAIRN D.J. 1997: Allometry for sexual size dimorphism: Pattern and process in the coevolution of body size in males and females. Annu. Rev. Ecol. Syst. 28: 659-687.

Fehrenbach H. 2003: Eggs. In Kristensen N.P. (ed.): Lepidoptera, Moths and Butterflies. Vol. 2. Morphology, Physiology and Development. Handbuch der Zoologie 4(36). Walter de Gruyter, Berlin, pp. 469-493.

Felsenstein J. 1985: Phylogenies and the comparative method. Am. Nat. 125: 1-15.

Felsenstein J. 2004: PHYLIP (Phylogeny Inference Package) version 3.6. Department of Genome Sciences, University of Washington, Seattle.

Fischer K. \& FiedLer K. 2001: Egg weight variation in the butterfly Lycaena hippothoe: more small or fewer large eggs. Popul. Ecol. 43: 105-109.

Fischer K., Bot A.N.M., Brakefield P.M. \& ZwaAn B.J.C. 2003: Fitness consequences of temperature-mediated egg size plasticity in a butterfly. Funct. Ecol. 17: 803-810.

Fischer K., O'Brien D.M. \& Boggs C.L. 2004: Allocation of larval and adult resources to reproduction in a fruit-feeding butterfly. Funct. Ecol. 18: 656-663.

Forte S.N., Ferrero A.A. \& Alonso T.S. 2002: Content and composition of phosphoglycerols and neutral lipids at different developmental stages of the codling moth, Cydia pomonella (Lepidoptera: Tortricidae). Arch. Insect Biochem. Physiol. 50: 121-130.

Fox C.W. \& CzesaK M.E. 2000: Evolutionary ecology of progeny size in arthropods. Annu. Rev. Entomol. 45: 341-369.

García-Barros E. 1994: Egg size variation in European Satyrine butterflies (Nymphalidae, Satyrinae). Biol. J. Linn. Soc. 51: 309-324.

García-Barros E. 2000: Body size, egg size, and their interspecific relationships with ecological and life history traits in butterflies (Lepidoptera: Papilionoidea, Hesperioidea). Biol. J. Linn. Soc. 70: 251-284.

García-Barros E. \& Martin J. 1995: The eggs of European satyrine butterflies (Nymphalidae): external morphology and its use in systematics. Zool. J. Linn. Soc. 115: 73-115.

Giron D. \& CASAS J. 2003: Mothers reduce egg provisioning with age. Ecol. Lett. 6: 273-277.

GouLD S.J. 1966: Allometry and size in ontogeny and phylogeny. Biol. Rev. 41: 587-640.

Harvey P.H. \& Pagel M.D. 1991: The Comparative Method in Evolutionary Biology. Oxford University Press, Oxford, 239 pp.

Hinton H.E. 1981: Biology of Insect Eggs. Vols 1-3. Pergamon Press, Oxford, xiii +777 pp.

HoNĚK A. 1993: Intraspecific variation in body size and fecundity in insects: a general relationship. Oikos 66: 483-492.

Johnson R.A. \& Wichern D.E. 2002: Applied Multivariate Statistical Analysis. 5th ed. Pearson Education, London, 767 pp.

Jutzeler D. \& De Bros E. 1996: Satyrus ferula (Fabricius 1793) from Valais (Switzerland): Extraordinarily long duration of larval emergence in stage L1 (Lepidoptera: Nymphalidae, Satyrinae). Linn. Belg. 15: 315-316.

KARLSSON B. 1987: Variation in egg weight, oviposition rate and reproductive reserves with female age in a natural population of the speckled wood butterfly, Pararge aegeria. Ecol. Entomol. 12: 473-476.

KARLsSON B. \& WiKLund C. 1984: Egg weight variation and lack of correlation between egg weight and offspring fitness in the wall brown butterfly, Lasiommata megera. Oikos 43: 376-385.

KARLSSON B. \& WiKLUND C. 1985: Egg weight variation in relation to egg mortality and starvation endurance of newly hatched larvae of satyrid butterflies. Ecol. Entomol. 10: 205-211.

KARLSSON B. \& WiKLUND C. 2005: Butterfly life history and temperature adaptations; dry open habitats select for increased fecundity and longevity. J. Anim. Ecol. 74: 99-104.

Kobayashi Y., Tanaka M. \& Ando H. 2003: Embryology. In Kristensen N.P. (ed.): Lepidoptera, Moths and Butterflies. Vol. 2. Morphology, Physiology and Development. Handbuch der Zoologie 4(36). Walter de Gruyter, Berlin, pp. 495-544.

Koztowski J., Konarzevski M. \& Gawelczyk A.T. 2003: Intraspecific body size optimization produces interspecific allometries. In Blackburn T.M. \& Gaston A.J. (eds): Macroecology. Concepts and Consequences. Blackwell Science, Malden, pp. 229-320.

Martin J.F., Gilles A. \& Descimon H. 2000: Molecular phylogeny and evolutionary patterns of the European Satyrids (Lepidoptera: Satyridae) as revealed by mitochondrial gene sequences. Mol. Phylogen. Evol. 15: 70-82.

Martins E.P. \& GarLand T. 1991: Phylogenetic analyses of the correlated evolution of continuous characters: a simulation study. Evolution 45: 534-557.

Mevi-Schütz J. \& ERhardt A. 2002: Can Inachis io detect nectar amino acids at low concentrations? Physiol. Entomol. 27: $256-260$.

Mevi-Schütz J. \& ERhardt A. 2005: Amino acids in nectar enhance butterfly fecundity: a long-awaited link. Am. Nat. 165: 411-419.

Molleman F., Grunsven R.H.A., Liefting M., ZwaAn B.J. \& BRAKEFIELD P.M. 2005: Is male puddling behaviour of tropical butterflies targeted at sodium for nuptial gifts or activity? Biol. J. Linn. Soc. 86: 345-361.

Munguira M.L., García-Barros E. \& Martín J. 1997: Plantas nutricias de los licénidos y satirinos españoles (Lepidoptera: Lycaenidae y Nymphalidae). Boln. Asoc. Esp. Entomol. 21: $29-53$.

NAKASUJI F. 1987: Egg size of skippers (Lepidoptera: Hesperiidae) in relation to their host specificity and to leaf toughness of host plants. Ecol. Res. 2: 157-183.

NAKASUII F. \& KimURA M. 1984: Seasonal polymorphism of egg size in a migrant skipper, Parnara guttata guttata (Lepidoptera: Hesperiidae). Kontyu 52: 253-259.

O’Brien D.M., Fogel M. \& Boggs C.L. 2002: Renewable and non-renewable resources: the role of amino-acid turnover in allocation to reproduction in Lepidoptera. Proc. Natl. Acad. Sci. USA 99: 4413-4418.

O’Brien D.M., Boggs C.L. \& Fogel M.L. 2004: Making eggs from nectar: the role of life history and dietary carbon turnover in butterfly reproductive resource allocation. Oikos 105: 279-291.

ReIss M.J. 1989: The Allometry of Growth and Reproduction. Cambridge University Press, Cambridge, $182 \mathrm{pp}$.

Rivero A. \& CASAS J. 1999: Rate of nutrient allocation to egg production in a parasitic wasp. Proc. R. Soc. Lond. (B) 266: $1169-1174$.

Rivero A., Giron D. \& Casas J. 2001: Lifetime allocation of juvenile and adult nutritional resources to egg production in a holometabolous insect. Proc. R. Soc. Lond. (B) 268: 1231-1238.

Roff D.A. 2002: Life History Evolution. Sinauer, Sunderland, $527 \mathrm{pp}$.

Rose M.R. \& BRAdley T.J. 1998: Evolutionary physiology of the cost of reproduction. Oikos 83: 443-451. 
Schmidt-Nielsen K. 1984: Scaling. Why is Animal Size so Important? Cambridge University Press, Cambridge, $241 \mathrm{pp}$.

Schwenk K. 2002: Constraint. In Pagel M. (ed.): Encyclopedia of Evolution. Oxford University Press, Oxford, pp. 196-199.

Shapiro J.P. \& Ferkovich S.M. 2002: Yolk protein immunoassays (YP-ELISA) to assess diet and reproductive quality of mass-reared Orius insidiosus (Heteroptera: Anthocoridae). $J$. Econ. Entomol. 95: 927-935.

Sinervo B. 1993: The effect of offspring size on physiology and life history. Bioscience 43: 210-218.

Smith C.C. \& Fretwell S.D. 1974: The optimal balance between size and number of offspring. Am. Nat. 108 499-506.

StatSoft Inc. 2004: STATISTICA (Data Analysis Software System), Version 6.1. (www.statsoft.com).

StARCK J.M. 1998: Non-independence of data in biological comparisons. A critical appraisal of current concepts, assumptions, and solutions. Theor. Biosci. 117: 109-138.

StJernholm F. \& Karlsson B. 2000: Nuptial gifts and the use of body resources for reproduction in the green-veined white butterfly Pieris napi. Proc. R. Soc. Lond. (B) 267: 807-811.

Thomas J.A., Munguira M.L., Martin J. \& Elmes G.W. 1991: Basal hatching by Maculinea butterfly eggs: a consequence of advanced myrmecophily? Biol. J. Linn. Soc. 44: 175-184.
Torres-Vila L.M. \& Rodríguez-Molina M.C. 2002: Egg size variation and its relationship with larval performance in the Lepidoptera: the case of the European grapevine moth Lobesia botrana. Oikos 99: 272-283.

Wall R., Wearmouth V.J. \& Smith K.E. 2002: Reproductive allocation by the blow fly Lucilia sericata in response to protein limitation. Physiol. Entomol. 27: 267-274.

Wedell N. \& Karlsson B. 2003: Paternal investment directly affects female reproductive effort in an insect. Proc. R. Soc. Lond. (B) 270: 2065-2071.

WhEeLER D. 1996: The role of nourishment in oogenesis. Annu. Rev. Entomol. 41: 407-431.

WIKLUND C. \& KARLSSON B. 1984: Egg size variation in satyrid butterflies: adaptive vs historical 'Bauplan', and mechanistic explanations. Oikos 43: 391-400.

Wiklund C. \& Persson A. 1983: Fecundity, and the relation of egg weight variation to offspring fitness in the speckled wood butterfly Pararge aegeria, or why don't butterfly females lay more eggs? Oikos 40: 53-63.

Williams A.E., Rose M.R. \& Bradley T.J. 2005: The respiratory pattern in Drosophila melanogaster selected for dessication resistance is not associated with the observed evolution of decreased locomotory activity. Physiol. Zool. 77: 10-17.

Received November 9, 2005; revised and accepted February 27, 2006 